\title{
PELAKSANAAN SִULH DALAM KES MELIBATKAN TUNTUTAN HARTANAH ORANG-ORANG ISLAM DI MAHKAMAH SYARIAH DI MALAYSIA: TINJAUAN TERHADAP KAJIAN LEPAS
}

\section{The Implementation of Șulh involving Real Estate Claims \\ of Muslims in Shariah Court in Malaysia: A Survey of Previous Studies}

\author{
Wan Azimin Wan Adnan \\ Ph.D Candidate, Department of Shariah and Law, \\ Academy of Islamic Studies, \\ University of Malaya, 50603 Kuala Lumpur \\ wanaziminlawyer72@gmail.com.my \\ Ahmad Hidayat Buang \\ Professor, Department of Shariah and Law, \\ Academy of Islamic Studies, \\ University of Malaya, 50603 Kuala Lumpur \\ ahidayat@um.edu.my
}

\begin{abstract}
Shariah Court's jurisdiction in Malaysia is limited in resolving dispute in matters relating Muslim personal and family law. When it comes to the decision and delivering judgement regarding Muslim's real estate, most of it will be placed under the jurisdiction of Federal Court and Civil High Court. This article discusses issues related to the implementation of sulh in the Shariah Court in Malaysia, especially in cases involving real estate claims of Muslims. This article will identify previous studies and related researches with regard to sulh as one of the alternative disputes resolution (ADR) as an effective role to end the dispute and save the court's time and fulfil the needs of the parties. Numbers of researches have been done regarding the implementation of sulh, however only matter regarding Muslim family cases were covered


while the study in resolving disputes on Muslim's real estate is insufficient or rarely been studied. The study found that sulh plays an important roles as quick resolution based on sufficient statutory basis. Nevertheless few recommendations and suggestions should be imposed in order to solve legal conflicts and administrative of agencies related to Muslims real estate in Malaysia.

Keywords: sulh, real estate claims of Muslim, Shariah Court's jurisdiction, Alternative Dispute Resolution (ADR), land administration

\section{PENDAHULUAN}

Perkembangan pentadbiran Mahkamah Syariah yang dilaksanakan kini telah menjadikan proses sulh sebahagian daripada amalan pentadbiran dan prosedur mal. Șulh merupakan salah satu penyelesaian pertikaian alternatif yang efektif kepada masyarakat selain proses perbicaraan, mediasi dan timbangtara untuk mendapatkan penyelesaian. Tan Sri Sheikh Ghazali Abdul Rahman, mantan Ketua Hakim Syarie JKSM pernah menyatakan bahawa pelaksanaan șulh akan diperkemaskan dari masa ke semasa dan akan dijadikan 'core bussiness' Mahkamah Syariah seluruhnya dalam usaha mempercepatkan penyelesaian kes (Sheikh, 2006: 243-260).

Sulh telah diperuntukkan dengan jelas di dalam statut berkaitan tatacara mal di Mahkamah Syariah negeri-negeri sebagaimana dinyatakan dalam seksyen 99, Akta Tatacara Mal Mahkamah Syariah (Wilayah-wilayah Persekutuan) 1998. Bagi maksud pelaksanaan maka Kaedah Tatacara Mal (Sulh), Manual Kerja Sulh JKSM, Arahan Amalan dan perundangan-perundangan yang berkaitan merupakan punca kuasa bagi melicinkan pelaksanaan șulh di Mahkamah Syariah.

Perkembangan positif Mahkamah Syariah di Malaysia memperkenalkan sulh sebagai pendekatan penyelesaian tuntutan secara damai yang murah dan ringkas telah mendapat sambutan yang baik dari masyarakat(Ridzuan, 2009). Keberkesanan pelaksanaan șulh di Mahkamah-mahkamah Syariah di seluruh negara dapat dilihat melalui peratusan yang tinggi kes berjaya diselesaikan dan membuktikan bahawa kaedah ini mampu untuk mengurangkan masalah kes tertangguh yang membelenggu Mahkamah Syariah selama ini (Adzidah Yaakob et al, 2016: 60)

Artikel ini membincangkan sorotan literatur berkaitan pelaksanaan șulh dalam kes melibatkan hartanah orang-orang Islam di Mahkamah Syariah di Malaysia. Terdapat tiga subtajuk dikemukakan bagi tujuan perincian iaitu 
Pelaksanaan Sulh dalam Kes Melibatkan Tuntutan Hartanah Orang-Orang Islam di Mahkamah Syariah di Malaysia

konsep șulh dalam perundangan Islam, pelaksanaan șulh di Mahkamah Syariah dan bidangkuasa Mahkamah Syariah dalam pentadbiran hartanah.

\section{KONSEP SִULH DALAM PERUNDANGAN ISLAM}

Penggunaan istilah șulh di dalam al-Quran dan as-Sunnah dijadikan asas perbincangan kajian bagi menjelaskan pengertian dan konsep șulh secara lebih luas mengikut perspektif perundangan Islam. Umumnya terdapat banyak kajian yang telah dilaksanakan bagi membincangkan konsep șulh yang telah dibuat oleh pengkaji tempatan dan luar negara. Shafi Fazaluddin (2016: 333358) dalam penulisannya berkaitan etika perdamaian di dalam al-Quran telah mentakrifkan șulh sebagai perdamaian. Kajian ini menganalisis konsep șulh dan etikanya secara holistik dan analitikal berdasarkan kepada peruntukan di dalam al-Quran. Said Bouheraoua (2010: 388) turut mempunyai pandangan yang sama dan berpendapat șulh adalah bermaksud perdamaian dan berbeza dengan wasatah atau mediasi. Manakala terdapat beberapa orang penulis yang turut menghurai maksud șulh di dalam al-Quran dan al-Sunnah pada sudut pengertian bahasa dan istilah fiqh, seterusnya mengaitkannya dengan pelaksanaan șulh pada zaman Rasulullah SAW dan para sahabat (al-Ramahi, 2008: 7-12; Bouheraoua, 2010: 388-393; Raihanah, 2005: 4-9; Ramizah, 2008: 35-38).

Pengkaji mendapati bahawa șulh didefinisikan sebagai perdamaian oleh sesetengah penulis berpandukan pemahaman terhadap penggunaan kata nama sulh di dalam al-Quran. Pemahaman ini selaras dengan makna șulh dari sudut pengertian Bahasa Arab. Melalui penulisan yang telah dihasilkan, pengertian dan konsep șulh adalah merujuk kepada apa yang telah dijelaskan di dalam beberapa ayat al-Quran. Umpamanya di dalam al-Quran:

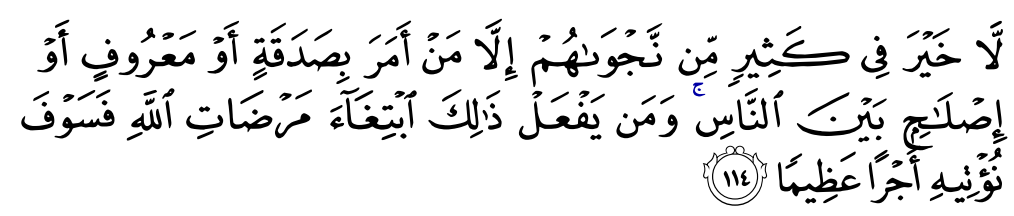

"Tidak ada kebaikan pada kebanyakan bisikan-bisikan mereka, kecuali (bisikan-bisikan) orang yang menyuruh bersedekah, atau berbuat kebaikan, atau mendamaikan di antara manusia. Dan sesiapa yang berbuat demikian dengan maksud mencari keredhaan Allah, tentulah kami akan memberi kepadanya pahala yang amat besar" 
Penulisan berkaitan konsep șulh juga merangkumi perbincangan yang merujuk kepada teks fiqh klasik sebagaimana yang dihurai oleh penulisan yang membincangkan șulh mengikut perspektif hukum Islam. Perbincangan berkaitan șulh di dalam kitab-kitab fiqh kebanyakannya diletakkan di bawah bab muamalah melibatkan kehartaan. Ramizah menyatakan perbincangan konsep șulh secara panjang lebar terdapat di dalam bab khusus iaitu Kitab al-Sulh karangan Ibn Abidin (1966) di dalam kitabnya Radd al-Muhtar ala ad-Dur al-Mukhtar (2008). Raihanah Azahari dalam penulisannya turut membincangkan konsep șulh berdasarkan kepada pandangan sarjana Islam berpandukan penulisan teks fiqh Islam. Namun penulis mendapati sarjanasarjana fiqh tidak menyusun perbincangan berkaitan șulh berkaitan dengan kekeluargaan Islam di dalam bab yang khusus melainkan al-Nazzam (t.t) dalam karangannya al-Fatawa al-Hinddiyyah. Perbincangan berkaitan șulh di dalam kitab berkenaan dibahagikan kepada 21 bab di bawah Kitab al-Sulh yang turut menyentuh aspek șulh dalam pertikaian nikah, talak, nafkah dan sebagainya (Raihanah, 2008).

Maka melalui huraian yang diperincikan, șulh diambil daripada perkataan Arab berasal darikata kerja șalaha yang bermaksud al-tasaluh wa al-musalamah iaitu saling berdamai selepas saling bertikai (al-Nasafī, 1997: 259). Manakala pengertian șulh secara literalnya bermaksud menamatkan pertikaian (Sayyid Sābiq, 1990: 305). Pengertian șulh secara terminologi adalah bermaksud akad bagi menamatkan pertikaian antara pihak-pihak yang bersengketa secara damai (al-Sharbin̄̄, 1944: 177). Menurut Wahbah Zuhaylī (1989: 293), șulh merupakan satu perjanjian yang dimeterai bagi menyelesaikan sesuatu konflik. Manakala Ibn Qudamah (1995: 236) mendefinisikan șulh sebagai perjanjian antara dua pihak yang bertikai bagi mencapai perdamaian.

Kebanyakan penulis turut mengemukakan pandangan pelbagai mazhab khususnya dalam mazhab Shāfi ‘' Hanafī, Hanbalī dan Mālikī dalam penulisan tentang konsep șulh mengikut perspektif fiqh Islam. Melalui penulisanpenulisan fiqh tersebut banyak menyentuh berkaitan pembahagian șulh adalah terbahagi kepada lima bahagian, iaitu șulh di antara orang Islam dan orang kafir, șulh di antara pemerintah yang adil dan pemberontak, șulh di antara suami isteri yang dikhuatiri berlaku nusyuz, șulh yang tidak bersangkutan dengan harta dan sulh dalam pertikaian harta. Namun, di dalam kitab-kitab fiqh, perbincangan bab șulh yang khusus adalah terletak di dalam susunan bab muamalah dan turut dibincangkan berkaitan tajuk jual beli, sewaan, pinjaman dan ibra' '. Oleh itu, kategori sulh yang bersangkutan dengan harta adalah lebih mendominasi perbincangan berkaitan tajuk șulh di dalam kitab fiqh.

Di dalam Majallah al-Ahkam al-Adliyyah yang mempunyai pengaruh fiqh Hanafi yang telah dijadikan teks perundangan dan dikanunkan oleh kerajaan 
Uthmaniyyah di Turki dari aspek muamalah, peruntukan-peruntukan yang menyentuh konsep dan perbincangan berkaitan șulh turut diperuntukkan (al-Ramahi, 2008; Syed, 2004). Definisi șulh disebut di dalam Artikel 1531 Majallah al-Ahkam al-Adliyyah tersebut sebagai akad yang menamatkan pertikaian secara sukarela atau saling redha-meredhai (Md. Akhir, 1990: 523). Berdasarkan kepada definisi ini șulh adalah merupakan perjanjian di antara dua pihak yang bertikai bagi maksud mencapai persetujuan di atas apa-apa syarat yang dipersetujui bersama secara sukarela. Perjanjian persetujuan yang dicapai itu sudah semestinya mengikat pihak-pihak untuk mematuhinya kerana ianya selaras dengan Hukum Syarak dan undang-undang.

Penggunaan istilah șulh dan konsepnya telah dinyatakan dan difahami daripada beberapa ayat al-Quran dan al-Sunnah. Antaranya dalam surah alBaqarah (2): 182 dan 224. Surah al-Anfal (8): 1, Surah al-Nisa' (4): 114, Surah al-Hujurat (49): 9-10 dan peruntukan-peruntukan hadis misalnya hadis yang diriwiyatkan oleh al-Bukhari dalam kitab al-Sulh, hadis riwayat Muslim (2605), al-Tirmidhī (1352) dan selainnya.

Firman Allah SWT di dalam al-Quran:

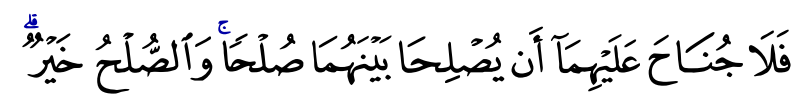

"Maka tiadalah salah bagi mereka (suami isteri) membuat perdamaian di antara mereka berdua (secara yang sebaikbaiknya), kerana perdamaian itu lebih baik (bagi mereka daripada bercerai-berai)"

(Surah al-Nisā', 4: 128)

Hadis Rasulullah SAW yang telah diriwayatkan oleh al-Tirmidhī dari Amru bin 'Awf:

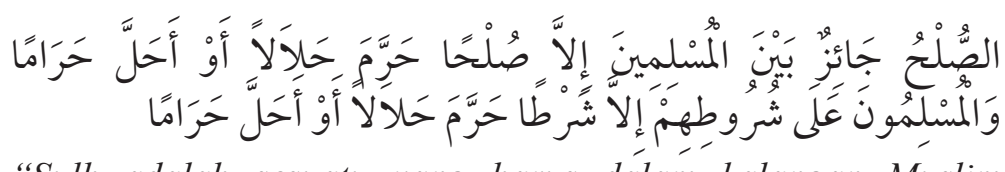

"Ṣulh adalah sesuatu yang harus dalam kalangan Muslim kecuali șulh yang mengharamkan sesuatu perkara yang halal atau sulh yang menghalalkan sesuatu yang haram, dan orang Islam adalah terikat dengan syarat (janji) yang dibuat mereka melainkan syarat (janji) untuk mengharamkan yang halal atau menghalalkan yang haram." 
Terdapat juga para pengkaji yang menyamakan șulh dengan mediasi berdasarkan pemahaman umum sebagaimana amalan sistem perundangan sivil masa kini kerana tujuan kedua-dua kaedah penyelesaian alternatif tersebut adalah untuk mencapai persetujuan atau perdamaian melalui proses perantaraan (Raihanah, 2009; Ramizah, 2008). Persamaan antara sulh dan mediasi juga pada sudut pelaksanaannya kerana kedua-duanya adalah melalui proses pengantaraan yang dikendalikan oleh pihak ketiga yang bebas, yang kuasanya terletak di atas persetujuan pihak-pihak dan memudahkan rundingan antara mereka (Hakimah, 2012: 98). Namun terdapat juga penulisan yang mengkaji perbandingan antara sulh dan mediasi telah dilaksanakan bagi melihat kelebihan dan kekurangan antara kedua-dua metod tersebut bagi penyelesaian kes di mahkamah (Mohammad Hafiz et al, 2017).

Kebanyakan penulis akan mengaitkan perbincangan berkaitan șulh dengan 'Alternative Dispute Resolution' (ADR) atau dalam bahasa Malaysianya dikenali sebagai penyelesaian pertikaian alternatif. Peranan sulh sebagai penyelesaian pertikaian alternatif menjadi satu perbincangan yang lebih luas dalam kalangan penulis dan kerap membandingkannya dengan mediasi yang digunapakai secara meluas di negara-negara lain. ADR adalah pendekatan penyelesaian pertikaian alternatif yang menjadi elemen penting dalam sistem kehakiman sivil masa kini. ADR adalah satu istilah yang merujuk kepada apa-apa proses bagi tujuan menyelesaikan pertikaian tanpa melalui proses perbicaraan di mahkamah yang berkemungkinan mendapat liputan yang negatif, menimbulkan ketidak-puashatian pihak-pihak yang bertikai dan memakan masa serta wang. Sehubungan dengan itu, Mahkamah Syariah di Malaysia telah melaksanakan konsep ADR tersebut pada aspek penyelesaian kes-kes kekeluargaan di mahkamah melalui proses perdamaian, hakam dan inisiatif hakim sendiri (Aida Othman, 2001: ccxxviii).

Ramizah (2007) dalam penulisannya telah melakukan perbandingan antara konsep șulh dengan mediasi serta amalannya di Mahkamah Syariah di Malaysia dan Singapura. Menurut penulis, mediasi adalah istilah moden mirip kepada konsep șulh. Mengikut pandangan penulis, perkataaan șulh membawa maksud yang lebih umum. Mediasi, tahkim, perundingan dan perdamaian boleh dikategorikan sebagai cara-cara penyelesaian melalui șulh. Șulh digunapakai di dalam Mahkamah Syariah di Malaysia, manakala mediasi adalah suatu kemestian bagi kes-kes melibatkan perkahwinan dan perceraian di Singapura (Ramizah, 2007: 137-140).

Pandangan sedemikian juga dikongsi oleh penulis yang lain seperti Raihanah Azhari yang menghuraikan konsep șulh adalah segala proses bagi maksud menyelesaikan pertikaian dan terkandung di bawahnya perundingan, wakalah, arbitrasi dan sebagainya. Mediasi merupakan kaedah atau proses 
bagi mencapai șulh atau perdamaian, sama seperti kaedah-kaedah lainnya seperti perundingan, wakalah dan arbitrasi (Raihanah, 2009: 99).

Kamal Halili (2014: 28) juga mempunyai pandangan tersendiri dengan menjelaskan teori penyelesaian pertikaian, makna dan bentukADR berdasarkan kepada kajian literatur. Menurut penulis, Islam mengiktiraf kedua-dua kaedah pengadilan dan mekanisme penyelesaian pertikaian iaitu secara konvensional atau alternatif. Sulh adalah satu cara penyelesaian pertikaian yang paling asas dalam menyelesaikan pertikaian. Penulis berpendapat kaedah-kaedah penyelesaian secara șulh adalah termasuk secara pengantaraan, perdamaian, perundingan dan bertolak ansur.

Syed Khalid Rashid (2004: 96) melalui penulisannya telah menganalisis kedudukan sulh adalah sebahagian daripada ADR yang terdapat dalam perundangan Islam dan menerangkan konsep sulh menurut Hukum Syarak selain pendekatan ADR yang lain merangkumi perundingan (negotiation), perdamaian (conciliation), mediasi (mediation), tahkim (arbitration), campuran di antara mediasi dan arbitrasi dan muhtasib (ombudsman) dan seumpamanya.

Terdapat penulisan berkaitan pelaksanaan ADR khususnya pendekatan șulh dan mediasi di Malaysia dan membandingkannya dengan negara-negara yang lain. Aida Othman (2001) menulis berkaitan tentang kepentingan ADR, prospek masa depan dan cabaran pelaksanaannya di Malaysia. Penulis membuat andaian bahawa ADR adalah merupakan suatu fenomena global dan telah dipraktikkan oleh sebahagian besar negara-negara maju seperti Amerika Syarikat, Kanada, Australia, New Zealand dan sesetengah negara Asia yang lain.

Terdapat juga penulisan tesis kedoktoran dari universiti luar negara sebagaimana penulisan Aida Othman (2005) sebagai satu kajian yang membuktikan șulh adalah penyelesaian pertikaian alternatif terbaik berdasarkan kepada undang-undang Islam. Penulisan-penulisan berkaitan șulh secara langsung turut dibincangkan bersekali dengan pendekatan perbandingan yang difokuskan kepada pelaksanaan ADR di negara-negara Komenwel bertujuan untuk mengemukakan reformasi ke atas pentadbiran sistem keadilan di negara berkenaan berpandukan kepada undang-undang Syariah (Oseni, 2011).

Pada pandangan pengkaji, perbezaan pemahaman berkaitan konsep șulh ini berpunca daripada tafsiran pengertian șulh yang diambil dari kata dasar 'salaha' dalam bahasa Arab dan dilihat konteks penggunaannya dalam al-Quran dan al-Sunnah. Sebahagian penulis berpendapat șulh adalah kata nama umum yang terkandung di dalamnya semua pendekatan seperti tahkim, perdamaian, mediasi dan sebagainya. Manakala sesetengah yang lain melihatnya sebagai 
kata nama khusus yang menjurus kepada pendekatan șulh yang mempunyai syarat dan rukunnya tersendiri.

Walaupun terdapat pelbagai huraian berkaitan dengan șulh, aspek ini tidak memberi kesan pada sudut pemahaman konsep asasnya kerana ianya bergantung kepada pelaksanaan șulh sama ada dilaksanakan secara formal di mahkamah atau tidak formal. Oleh itu dari sudut perundangan hanya penyelesaian sulh yang dibuat perjanjian persetujuan oleh kedua-dua pihak yang diperakukan oleh mahkamah sahaja boleh mengikat pihak-pihak. Manakala apa-apa terma perjanjian yang dibuat tanpa perintah mahkamah dan tanpa melalui proses perundangan yang sah tidak diperakui oleh mahkamah, walaupun dari sudut Hukum Syarak setiap Muslim itu hendaklah menyempurnakan janjinya.

Pada sudut penyelidikan artikel ini, șulh dari konteks pelaksanaan di Mahkamah Syariah adalah merujuk kepada prosedur penyelesaian pertikaian alternatif secara formal melalui Majlis șulh di Mahkamah Syariah yang memberi kesan mengikat kepada pihak yang terlibat. Majlis șulh adalah satu majlis perundingan terpimpin secara rasmi yang diatur oleh mahkamah berdasarkan prosedur tertentu (Zaini Nasohah, 2010: 74). Sekiranya perdamaian atau persetujuan bersama dicapai, satu perintah mahkamah dikeluarkan. Sekiranya gagal atau tiada persetujuan maka kes akan diteruskan untuk perbicaraan.

\section{PELAKSANAAN SִULH DI MAHKAMAH SYARIAH DI MALAYSIA}

Kajian berkaitan tentang pelaksanaan șulh di Mahkamah Syariah adalah perbincangan yang menyentuh secara langsung berkaitan perundangan bagi prosedur yang digunapakai di Mahkamah Syariah. Proses pelaksanaan sulh telah diperincikan di dalam kaedah-kaedah tatacara mal (șulh) yang berpunca kuasa daripada akta atau enakmen prosedur mal Mahkamah Syariah Wilayah Persekutuan dan negeri-negeri. Kajian berkaitan tatacara mal syariah berkaitan șulh telah dibuat sebagaimana penulisan Ahmad Hidayat (2007b: 154) yang membincangkan secara ringkas berkaitan tentang șulh sebelum proses perbicaraan. Manakala Mohd Nazri (2010: 132-134) turut menyentuh secara ringkas berkaitan șulh berdasarkan seksyen 99 Enakmen Tatacara Mal Mahkamah Syariah (Negeri Sembilan) 2003. Menurut penulis sewaktu peruntukan ini diperuntukkan, kaedah-kaedah șulh Mahkamah Syariah belum lagi dilaksanakan, maka kaedah-kaedah Hukum Syarak hendaklah terpakai dalam memutuskan penyelesaian secara șulh.

Dari sudut perundangan, șulh dinyatakan secara jelas di bawah Akta atau Enakmen Tatacara Mal Mahkamah Syariah Wilayah Persekutuan atau negeri-negeri. Contohnya di bawah peruntukan seksyen 99, Akta Tatacara 
Mal Mahkamah Syariah (Wilayah-wilayah Persekutuan 1998) menjelaskan bahawa mana-mana pihak yang bertikai boleh merujuk kes mereka kepada sulh pada mana-mana peringkat prosiding di mahkamah sebelum keputusan dan perintah dikeluarkan oleh hakim. Manakala pada seksyen 246(1)(c) akta yang sama memperuntukkan Jawatankuasa Kaedah Mahkamah Syariah boleh membuat apa-apa peraturan bagi menjalankan prosedur șulh.

Namun, definisi șulh tidak diterangkan makna dan konsep șulh sebagaimana yang dikehendaki oleh akta atau enakmen terbabit yang biasanya dijelaskan di dalam seksyen 2 di bawah tajuk tafsiran di dalam mana-mana akta atau enakmen Mahkamah Syariah. Ketiadaan peruntukan yang mendefinisikan șulh ini memberi kelonggaran kepada hakim bicara untuk menerima permohonan pihak-pihak atau memerintahkan kes dirujuk kepada mana-mana sesi șulh yang mampu berperanan dan bertindak untuk mencari penyelesaian kes tersebut secara perdamaian. Hakim syarie turut boleh menggunakan budi bicara mereka untuk bertindak sendiri untuk menjadi pengantara antara pihakpihak yang bertikai di luar proses perbicaraan.

Bagi melicinkan lagi proses pelaksanaan șulh, tidak memadai hanya bergantung kepada peruntukan seksyen yang khusus berkaitan șulh dalam undang-undang Tatacara Mal Mahkamah Syariah dan Kaedah Tatacara Mal Sulh, maka turut diperkenalkan Arahan Amalan untuk tujuan penyelarasan pelaksanaan șulh di Mahkamah Syariah. Mazni Abdul Wahab (2014) melalui penulisan tesis kedoktorannya telah menghuraikan kedudukan sulh dan kepentingannya dalam penyelesaian kes di Mahkamah Syariah melalui perbincangan terhadap Arahan Amalan yang telah dikeluarkan oleh Jabatan Kehakiman Syariah Malaysia (JKSM) berkaitan șulh (Mazni, 2014). Namun Arahan Amalan tersebut adalah setakat perkembangan kajian tersebut yang berakhir pada tahun 2012. Pengkaji turut mendapati bahawa perkembangan Arahan Amalan yang telah dikeluarkan oleh JKSM dan diendors oleh negerinegeri terus mengalami penambahbaikan. Sebagai contoh, Arahan Amalan No 7/ Tahun 2015 yang bertajuk "Penyeragaman Proses kerja Dan Carta Aliran Sulh Di JKSN/MSN Seluruh Malaysia" memberi garis panduan yang hampir lengkap bagi pelaksanaan șulh yang berkesan.

Pengkaji mendapati bahawa penulisan-penulisan yang menyentuh berkaitan perundangan bagi prosedur mal berkaitan șulh hanya membincangkan kaedahkaedah tatacara mal negeri-negeri tertentu sahaja dan tidak menyentuh secara keseluruhan perundangan-perundangan di keseluruhan negeri di Malaysia. Walaupun kaedah-kaedah tatacara mal (sulh) untuk dijadikan garis panduan kepada Pegawai Șulh di Mahkamah-Mahkamah Syariah negeri-negeri tertentu telah digubal dan digazetkan, namun antara setiap negeri tersebut adalah 
tidak seragam. Masih terdapat negeri-negeri yang masih belum mempunyai Kaedah-kaedah Prosedur Mal (Șulh) yang khusus dan ada negeri yang masih belum menguatkuasakannya (Dahlan, Palil, Mohamad, \& Yaakub, 2017: 8698). Manakala dari sudut pelaksanaan șulh di negeri-negeri terbabit adalah berpandukan kepada Manual Kerja Șulh JKSM dan bantuan sistem berasaskan internet E-syariah (Modul Șulḥ).

Pada dimensi yang lain, terdapat juga penulisan pelaksanaan șulh dalam kes-kes jenayah turut didapati seperti di dalam penulisan Norjihan Ab. Aziz dan Nasimah Hussin (2016) yang menyentuh berkaitan pelaksanaan sulh dalam undang-undang jenayah Islam. Manakala Hussin dan Ramizah (2008) turut membincangkan tentang peranan mediasi di dalam kes-kes jenayah dan aplikasi șulh di dalam kes-kes jenayah di negara-negara Islam. Memandangkan peruntukan berkaitan șulh di dalam kes-kes jenayah tidak diperuntukkan di dalam undang-undang tatacara jenayah Mahkamah Syariah di Malaysia dan tidak dijadikan amalan di negara ini, maka penulisan-penulisan yang dihasilkan tersebut banyak menyentuh berkaitan șulh di dalam aspek undangundang jenayah Islam khususnya berkaitan qișās dan diyat.

Terdapat juga penulisan yang membincangkan pendekatan șulh di luar dari konteks Mahkamah Syariah sebagai penyelesaian alternatif terhadap pertikaian pihak-pihak sebagaimana Raini Hassan et al (2013) telah menulis satu artikel yang menyentuh pendekatan penyelesaian mediasi secara atas talian bagi penyelesaian pertikaian yang berlaku didalam masyarakat. Begitu juga Kamal Halili Hassan (2014: 124-135) membincangkan peranan penyelesaian alternatif dalam pertikaian industri berdasarkan kepada pendekatan Sivil dan Syariah.

Nora Abdul Hak (2007: 121-148) pula telah membincangkan secara umum pelaksanaan mediasi keluarga di Singapura, Jepun dan Hong Kong dalam penyelesaian kes pertikaian rumahtangga dengan merujuk amalan dan undang-undang di Malaysia. Penulisan beliau tersebut adalah tertumpu kepada perbincangan berkaitan Akta Memperbaharui Perkawinan dan Perceraian 1976 yang digunapakai bagi orang-orang bukan Islam di Malaysia.

Penulisan yang komprehensif berkaitan șulh dan hubungannya dengan ADR dapat dilihat melalui penulisan Nora Abdul Hak et. al (2011: 19-38) dalam penulisan buku bertajuk, Alternative Dispute Resolution (ADR) in Islam. Penulisan ini menghuraikan secara khusus berkaitan dengan șulh dari aspek Hukum Syarak, latar belakang, prinsip dan amalannya di Mahkamah Syariah Wilayah Persekutuan dan Selangor dalam bab yang berasingan (Ibid: 137-161). Penulisan ini memberi suatu landasan konsep yang menyeluruh 
berkaitan ADR dan șulh di dalam Islam dan pelaksanaannya di Malaysia selain menghurai perbezaannya dengan jawatankuasa pendamai dan hakam.

Penulisan terkini berkaitan șulh di Mahkamah Syariah telah dilaksanakan oleh Yaakob, Zakaria, Ahmad, Mohd, \& Halim (2016: 49-50) di dalam penulisan mereka yang memfokuskan kajian khusus terhadap keberkesanan proses pelaksanaaan șulh berdasarkan data statistik kes-kes șulh di Mahkamah Syariah Wilayah Persekutuan bermula tahun 2011 hingga tahun 2014. Penulis turut melihat aspek cabaran pelaksanaan șulh kini serta mengemukakan saranan penambahbaikan. Penulisan ini mengkaji isu pelaksanaan șulh secara umum tanpa menghadkan kajian khusus tentang aspek kes-kes yang melibatkan hartanah.

Penulisan berkaitan latar belakang pelaksanaan șulh di Malaysia dibincang oleh Hanis Wahed (2015: 71-79) yang mengkaji tentang latar belakang sejarah pelaksanaan șulh bermula pada zaman kesultanan Melayu Melaka dan perkembangannya kini telah berperanan dalam menyelesaikan kes-kes rumahtangga orang-orang Islam di Malaysia berteraskan kepada Al-Quran dan As-Sunnah. Ketua kampung, ulama, imam dan kadi di Mahkamah Syariah adalah mereka yang berpengaruh yang selalunya dirujuk bagi menyelesaikan pertikaian dalam masyarakat Melayu termasuk dalam pertikaian hartanah ( Ahmad Ibrahim, 1995: 1-10).

Sebelum era penjajahan Ingeris di Tanah Melayu, masyarakat Melayu telah mengamalkan sulh atau perdamaian dalam penyelesaian kes-kes kekeluargaan dan masyarakat secara tidak rasmi. Menurut Wan Halim Othman (1996: 30-42), perdamaian adalah aspek terpenting didalam sistem perundangan masyarakat di Asia. Orang yang lebih tua atau pemimpin dalam masyarakat akan dirujuk untuk menyelesaikan pertikaian yang berlaku dalam masyarakat. Melalui perdamaian ini pertikaian secara terbuka dapat dielakkan dan maruah pihak-pihak yang bertikai terpelihara.

Kajian berkaitan pelaksanaan șulh dan mediasi di Mahkamah Syariah turut menjadi tumpuan para pengkaji tempatan. Fokus kajian lebih tertumpu kepada aspek perundangan dan amalan di Mahkamah Syariah. Ramizah Wan Muhammad (2008: 33-35) turut membincangkan pelaksanaan șulh dari sudut teori dan praktikal di Mahkamah Syariah di Malaysia. Penulis menyentuh tentang latar belakang perkembangan șulh di Mahkamah Syariah di Malaysia bermula pelantikan Pegawai Șulh yang secara rasmi diperkenalkan dan dipraktikkan di Wilayah Persekutuan pada tahun 2001 diikuti dengan Selangor pada tahun 2002, Melaka pada September 2002 dan negeri-negeri lain seterusnya. Penulis merumuskan bahawa Pegawai Șulh memainkan peranan 
yang penting bagi pelaksanaan Majlis șulh yang berkesan bagi mencapai penyelesaian antara pihak-pihak yang bertikai._

Penulisan yang lebih fokus dalam aspek berkaitan pelaksanaan șulh di Mahkamah Syariah telah dilaksanakan oleh Raihanah Azahari (2004) yang menyentuh secara khusus proses pelaksanaan șulh di Mahkamah Syariah di Selangor sebagai satu pendekatan alternatif bagi mempercepatkan kes-kes yang tertangguh. Rujukan kepada statistik kes-kes șulh telah membuktikan keberkesanan pelaksanaan sulh tersebut yang menyumbang ke arah menyelesaikan masalah konflik dan pentadbiran dengan lebih cepat dan berkesan. Berdasarkan kepada kajian yang dihasilkan, kesimpulannya 220 kes atau 44 peratus daripada 500 kes yang dikaji mengambil masa antara sebulan atau kurang daripada sebulan untuk diselesaikan. Antara dapatan kajian tersebut, terdapat banyak kes yang mampu diselesaikan dalam tempoh hanya sehari sehingga tujuh hari.

Seterusnya penulis yang sama turut membuat kajian analisis terhadap pelaksanaan șulh dalam kes-kes kekeluargaan berdasarkan kajian di Jabatan Kehakiman Syariah Selangor (JAKESS) dari sudut methodologi șulh bagi penyelesaian kes kekeluargaan Islam. Peruntukan perundangan Enakmen undang-undang keluarga Islam, kaedah tatacara mal (șulh), manual kerja șulh, Arahan Amalan dan perundangan-perundangan yang berkaitan dijadikan sebahagian daripada kajian tersebut. Penulis menegaskan bahawa segala bentuk formaliti yang terkandung dalam prosedur șulh atau mediasi yang tidak bercanggah dengan prinsip șulh menurut Islam, tidak boleh dijadikan penghalang bagi mencapai tujuan menamatkan pertikaian antara pihak-pihak (Raihanah, 2009: 99).

Sheikh Ghazali (2006b) telah membincangkan secara terperinci berkaitan proses șulh menurut perundangan Islam dengan menghurai tentang Manual Kerja Sulh yang digunapakai di Mahkamah Syariah. Manual Kerja Sulh dan Kaedah-kaedah Tatacara Mal (Sulh) digubal bagi tujuan menjelaskan dan menyeragamkan prosedur yang perlu diikuti oleh semua Pegawai Sulh dalam mengendalikan Majlis Șulh di Mahkamah Syariah. Kewujudan manual kerja Șulh ini mampu melicinkan perjalanan Majlis Șulh dan mempercepatkan keskes Mahkamah Syariah yang tertangguh di seluruh negara dengan baik dan berkesan.

Manakala Sa'odah Ahmad dan Nora Abdul Hak (2011) turut membincangkan pelaksanaan șulh di Mahkamah Syariah di Selangor melalui kajian berdasarkan peruntukan-peruntukan undang-undang berkaitan. Berdasarkan kepada statistik kes șulh seluruh Mahkamah Syariah di Selangor bersumberkan kepada Jabatan Kehakiman Syariah Selangor (JAKESS) yang 
diambil daripada bulan Mei 2002 hingga Disember 2006, daripada jumlah keseluruhan kes sebanyak 7,872, kes yang dapat diselesaikan melalui șulh adalah berjumlah 5,044 atau 64 peratus berbanding kes yang gagal dan dirujuk kepada perbicaraan di hadapan hakim sebanyak 2,645 kes atau 34 peratus. Penulis telah membuktikan bahawa sulh telah berjaya menjadi pendekatan penyelesaian alternatif yang lebih berkesan berbanding kejayaan kes melalui proses litigasi (Nora, 2011).

Kajian empirikal terhadap keberkesanan pendekatan șulh dan kepuasan pelanggan juga turut dilaksanakan melalui kaedah soal selidik terhadap responden-responden di Mahkamah Syariah Wilayah Persekutuan dan Selangor. Dapatan kajian Saodah Ahmad et. Al (2013: 120-125) turut mendapati bahawa pelanggan amat bersetuju bahawa șulh adalah kaedah penyelesaian alternatif yang mampu menyediakan resolusi persetujuan bagi menyelesaikan kes-kes yang dipertikaikan. Kajian ini menggunakan kaedah persampelan bertujuan bagi memilih responden terdiri daripada klien-klien șulh di Mahkamah Syariah Wilayah Persekutuan Kuala Lumpur dan Putrajaya. Seramai 83 orang daripada 300 klien yang dipilih telah memberi persetujuan untuk menjawab soalan kajian berstruktur melalui telefon. Di Selangor, seramai 128 klien daripada 250 klien yang menerima borang yang diedar, telah menghantar borang kaji selidik semula kepada pihak penyelidik. Hasil dapatan kajian yang diperolehi sebanyak 79 peratus responden di Selangor dan 56 peratus di Wilayah Persekutuan Kuala Lumpur dan Putrajaya melaporkan bahawa șulh adalah satu proses penyelesaian pertikaian yang cepat, adil dan memberi ruang dan peluang kepada kedua-dua pihak yang bertikai untuk menyelesaikan masalah mereka secara baik melalui kaedah rundingan dan tolak ansur dengan bantuan Pegawai Sulh sebagai mediator.

Zainul Rijal (2011) pula membincangkan pendekatan șulh dari sudut perundangan dan amalannya di Mahkamah Syariah di Malaysia. Penulis juga turut memperkenalkan peranan peguam syarie bagi mengendalikan sesi șulh atau mediasi di mahkamah-mahkamah terbabit. Pengkaji mendapati perjanjian persetujuan yang menggunakan khidmat peguam syarie sebagai mediator adalah sesuatu perkembangan yang baru dan boleh diaplikasikan dengan lebih meluas di Mahkamah Syariah selain melalui proses majlis șulh seperti yang diamalkan sekarang. Pendekatan yang telah diamalkan di Mahkamah Sivil melalui Arahan Amalan No 5 Tahun 2010 berkaitan mediasi turut mengiktiraf perjanjian persetujuan yang dijalankan oleh mediator dalam kalangan peguam yang terlatih dibawah Pusat Mediasi Malaysia adalah sesuatu yang boleh dijadikan panduan dan dibuat kajian lanjut. 
Peranan dan kemampuan Pegawai Sulh di Mahkamah Syariah dalam penyelesaian konflik keluarga Islam telah dijadikan subjek kajian khusus oleh Mohd Fuad Mohd Salleh dan Jamilah Othman (2008: 37-48). Pendekatan kualitatif melalui kajian kes dipilih untuk menyempurna dan menjawab persoalan kajian tersebut iaitu memahami peranan Pegawai Șulh dalam menyelesaikan konflik. Dapatan kajian mendapati Pegawai Șulh menyelesaikan konflik dengan melaksanakan dua perkara asas utama iaitu tidak bertentangan dengan Hukum Syarak dan undang-undang serta berasaskan persetujuan bersama. Menurut penulis, Pegawai Sulh juga telah menjalankan dua peranan iaitu sebagai mediator dan kaunselor.

Terdapat juga penulisan yang membincangkan tentang șulh dari aspek berbeza daripada skop kekeluargaan. Penulisan Faridah Jalil dan Rohizan Halim (2014: 112-123) telah membincangkan peranan șulh atau mediasi dalam kes penukaran agama. Penulis melihat pendekatan șulh mampu untuk menyelesaikan konflik dua bidang kuasa mahkamah yang berbeza iaitu mahkamah sivil dan syariah yang menghadkan perbicaraan bagi kes-kes yang melibatkan orang-orang Islam sahaja. Penemuan ini boleh dijadikan sandaran bahawa faktor perbezaan agama pihak-pihak yang bertikai tidak menjadi penghalang ke arah menjayakan penyelesaian secara pendekatan șulh.

\section{BIDANGKUASA MAHKAMAH SYARIAH DALAM PENTADBIRAN HARTANAH}

Perbincangan berkenaan dengan bidangkuasa Mahkamah Syariah dalam pentadbiran hartanah orang-orang Islam adalah berkait rapat dengan sejarah perkembangan undang-undang Inggeris di Malaysia. Konflik bidangkuasa antara Mahkamah Sivil dan Syariah adalah berpunca daripada penjajahan dan campur tangan Inggeris yang telah memperkenalkan undang-undang Inggeris di Tanah Melayu khususnya bermula dengan Piagam Keadilan pada tahun 1826 dan sehinggalah diperkenalkan Ordinan Undang-Undang Sivil 1937 (Ahmad Ibrahim, 1989: 3-25). Sejarah perkembangan pentadbiran tanah di Semenanjung Tanah Melayu sebelum penjajahan Inggeris sehingga penggubalan Kanun Tanah Negara 1965 yang berasaskan Sistem Torrens Inggeris telah dijadikan subjek perbincangan sebahagian penulis. Pengetahuan tentang latar belakang sejarah perkembangan pentadbiran tanah di Malaysia adalah penting bagi memahami perkembangan undang-undang pentadbiran tanah kini (Ainul Jaria Maidin, 2014: 1-24).

Penulisan yang terawal dan lebih komprehensif berkaitan dengan latar belakang perkembangan undang-undang Islam dan Adat Melayu di Tanah Melayu telah dihasilkan oleh Ahmad Ibrahim (1965: 147) yang 
telah membincangkan berkaitan perkembangan sejarah dan status undangundang pentadbiran harta orang-orang Islam dengan mengemukakan kes-kes mahkamah sebagai rujukan. Penulisan-penulisan terdahulu oleh para pengkaji Inggeris turut menyentuh berkaitan sistem pentadbiran tanah di Tanah Melayu dan mengkaji pengaruh Islam dan Adat Melayu khususnya Adat Temenggung dan Adat Perpatih. MB Hooker (1970) turut berperanan mengumpul artikelartikel yang dihasilkan oleh pengkaji-pengkaji Inggeris seperti W.E Maxwell (1884), R.J. Wilkinson (1970), E.N Taylor (1948: 48) dan selain mereka dalam penulisannya. Tidak dinafikan penulisan-penulisan ini dijadikan sumber rujukan utama kepada pengkaji-pengkaji terkemudian bagi melihat latar belakang sejarah perundangan dan pentadbiran hartanah orang-orang Islam di Malaysia.

Sebelum sistem Torrens diperkenalkan di negeri-negeri Melayu, sudah terdapat satu sistem undang-undang dan pentadbiran tanah berasaskan Adat Melayu dan undang-undang Islam (Salleh Buang, 1993: 8). Melalui penghakiman kes-kes yang telah diputuskan oleh hakim Inggeris seperti di dalam kes Ramah lwn Laton (1927) 6 FMSLR 128 telah mengesahkan kedudukan undang-undang Islam bukan merupakan undang-undang yang asing bagi Tanah Melayu tetapi adalah sebagai undang-undang tempatan yang sepatutnya diberi pengiktirafan. Manakala di dalam kes Shaikh Abdul Latif \& Ors v Shaikh Elias Bux (1915) 1 FMSLR 204, hakim Inggeris telah memutuskan bahawa undang-undang Islam hendaklah terpakai dalam menentukan kesahan satu wasiat yang telah dibuat oleh seorang Islam di negeri Selangor.

Penegasan tentang status perundangan tanah sebelum penjajahan Inggeris juga didapati di dalam kes Tengku Jaafar \& Anor lwn State of Pahang [1987] 2 MLJ 74, hakim telah memutuskan bahawa undang-undang tanah di Pahang sebelum terlaksananya sistem Torrens ialah hukum Islam mengikut mazhab al-Shāfi' $\overline{1}$. Perkembangan pentadbiran tanah pada era sebelum penjajahan Inggeris dan kedudukan undang-undang tanah pasca penjajahan Inggeris memberi kesan terhadap perundangan dan pentadbiran tanah orang-orang Islam di Malaysia yang diamalkan kini.

Setelah negara mencapai kemerdekaan, Perlembagaan Persekutuan telah menjelaskan kedudukan agama Islam sebagai Agama Persekutuan. Namun kedudukan undang-undang Islam dihadkan sebagai undang-undang diri orang Islam dan kekeluargaan. Perlembagaan Persekutuan memberi kuasa kepada Badan Perundangan Negeri menggubal undang-undang bagi penubuhan Mahkamah Syariah dalam bidangkuasa negeri sebagaimana diperuntukkan di bawah Jadual Kesembilan Senarai Dua Senarai Negeri, Perlembagaan Persekutuan. Walaupun peruntukan itu menyatakan bahawa perkara berkaitan 
harta orang-orang Islam tersebut dimasukkan di bawah Senarai Negeri, terdapat beberapa undang-undang Persekutuan yang menghadkan bidangkuasa Mahkamah Syariah dan pemakaian enakmen negeri seperti Akta Probet dan Pentadbiran 1959, Akta Pembahagian Pusaka Kecil 1955, Akta Tanah (Kawasan Penempatan Berkelompok) 1960 dan sebagainya. Berpandukan keskes yang telah diputuskan oleh Mahkamah Sivil memperlihatkan kedudukan Undang-Undang Tanah di Malaysia turut mempunyai keistimewaannya tersendiri seperti melibatkan status anak negeri, tanah rezab Melayu, tanah adat dan sebagainya. Pindaan terhadap peruntukan-peruntukan di bawah Kanun Tanah Negara 1965 dibuat bagi menyelesaikan permasalahan-permasalah perundangan yang kompleks berkaitan dengan pentadbiran tanah di Malaysia (Sood \& Tee, 2012: 1).

Penulisan berkaitan bidangkuasa Mahkamah Syariah dalam kes-kes melibatkan harta orang-orang Islam turut menyentuh isu kesan pindaan Perkara 121 1(A) Perlembagaan Persekutuan yang telah menjelaskan kedudukan Mahkamah Sivil dan Syariah bagi memastikan tidak ada campur tangan dalam bidang kuasa masing-masing. Namun, berdasarkan kajian terhadap keskes yang diputuskan oleh mahkamah, campur tangan di dalam kes-kes yang sepatutnya dibicarakan di Mahkamah Syariah masih lagi berlaku khususnya apabila melibatkan salah satu pihak adalah bukan Islam (Ahmad Ibrahim, 2000: 37-60).

Berdasarkan kepada kehendak pindaan Perlembagaan Persekutuan Perkara 121 (1A), konflik bidang kuasa antara Mahkamah Syariah dan Mahkamah Sivil seharusnya tidak lagi berlaku. Namun disebabkan wujud beberapa faktor-faktor perundangan dan pentadbiran melibatkan bidangkuasa institusiinstusi terlibat, termasuk dalam hal ehwal pengurusan hartanah, maka konflik bidangkuasa antara mahkamah-mahkamah tersebut masih berlaku. Muhamed Azam Mohamed Adil dan Rafeah Saidon (2017: 176-177) telah memperincikan dua pendekatan yang diambil oleh Mahkamah Sivil apabila persoalan yang berkaitan dengan undang-undang Islam dibangkitkan. Pertama, pendekatan subjek atau perkara digunakan untuk menentukan bidang kuasa Mahkamah Syariah dan pendekatan yang kedua adalah berdasarkan kepada perintah yang dipohon.

Md Yazid (2010) pula telah membincangkan faktor-faktor tersebut dengan huraian berdasarkan kes-kes yang telah diputuskan. Penulis menyarankan agar pindaan-pindaan turut dibuat kepada beberapa peruntukan di dalam statutstatut seperti Akta Relif Spesifik 1950, Akta Keterangan 1950 dan sebagainya bagi mencapai maksud pindaan 121 1(A) Perlembagaan Persekutuan tersebut. 
Sehubungan dengan kajian-kajian yang telah dibuat, beberapa orang sarjana perundangan Islam seperti Professor Ahmad Ibrahim dan Dato Dr Monir (Yaacob, 2016) turut mengemukakan beberapa saranan dan cadangan penambahbaikan bagi penyelesaian isu konflik bidangkuasa tersebut. Antara saranan tersebut adalah menggubal undang-undang yang terletak di bawah bidangkuasa negeri khususnya berkaitan wakaf dan pindaan khusus berkaitan Akta Probet dan Pentadbiran di peringkat Persekutuan bagi memberi kuasa kepada Mahkamah Syariah untuk membicarakan kes pentadbiran hartanah orang-orang Islam (Ahmad Ibrahim, 2000: 37-60).

Usaha mengharmonikan pendekatan Mahkamah Syariah dan Sivil didalam memutuskan kes-kes melibatkan tuntutan harta orang-orang Islam juga disarankan bagi menyelesaikan konflik bidangkuasa kedua-dua institusi kehakiman tersebut. Menyedari realiti kedudukan dwi-sistem perundangan dan kehakiman negara, Tun Abdul Hamid Mohamad (2016: 63) melalui penulisannya telah menyarankan agar usaha pengharmonian dapat diadakan. Cadangan menempatkan hakim Mahkamah Sivil dan hakim Mahkamah Syariah di Mahkamah Sivil bagi menyelesaikan kes-kes yang melibatkan pertikaian bidangkuasa turut disarankan (Ismail Yahya, 2017: 21-22). Menilai saranansaranan yang telah dikemukakan tersebut, pengkaji mendapati masih belum ada cadangan berkaitan dengan pendekatan sulh bagi tujuan penyelesaian konflik antara dua institusi kehakiman terbabit. Oleh itu, pendekatan sulh perlu disarankan sebagai mekanisme yang terbaik untuk menyelesaikan segera permasalahan pentadbiran dan perundangan dwi-sistem kehakiman ini.

Terdapat beberapa penulisan yang menyentuh secara langsung berkaitan bidangkuasa Mahkamah Syariah dalam pentadbiran tanah sebagaimana penulisan Ahmad Ibrahim (2008) berkaitan bidangkuasa Mahkamah Syariah di dalam kes tuntutan harta orang-orang Islam di Malaysia dengan menumpukan kepada kes-kes yang telah diputuskan oleh mahkamah. Abdul Aziz Ismail (2014: 25-48) pula telah membincangkan isu bidangkuasa Mahkamah Syariah dalam pentadbiran tanah berdasarkan aspek perundangan. Penulisannya telah merumuskan jika perintah Mahkamah Syariah berkaitan dengan perletakhakan yang dalam bidangkuasanya, maka Pendaftar Hakmilik atau Pentadbir Tanah perlu menguatkuasakannya mengikut seksyen $420 \mathrm{KTN}$.

Namun, terdapat penulisan yang menjurus ke arah usaha memartabatkan Mahkamah Syariah dengan mempertingkatkan kuasa dan peranan Mahkamah Syariah di dalam undang-undang tanah. Rusnadewi Abdul Rashid (2013: 2736) telah menyarankan supaya Mahkamah Syariah menggunakan kuasa yang diberikan untuk memutuskan kes-kes hibah, wasiat, pusaka sebagaimana kuasa yang telah diberikan di dalam seksyen 421A Kanun Tanah Negara 
1965. Sedangkan Mahkamah Syariah telah diberi kuasa untuk mengeluarkan perintah menggunakan seksyen 417 untuk dikuatkuasa oleh Pendaftar Tanah.

Bidangkuasa Mahkamah Syariah bagi membicarakan kes-kes melibatkan harta sepencarian, hibah, wakaf, pusaka dan wasiat orang-orang Islam memberi skop kajian yang luas bagi setiap kes tersebut. Kebanyakan penulis menyentuh secara ringkas keperluan menggunakan pendekatan șulh bagi mendapat penyelesaian yang terbaik bagi kes-kes tersebut. Suwaid Tapah (2007: 74-75) dalam membincangkan berkaitan dengan harta sepencarian, menjelaskan tentang pendekatan secara șulh digunakan sama ada melalui pengakuan dan penyerahan hak pemilikan kepada satu pihak lagi atau nilai harta yang dipersetujui dibahagikan mengikut persetujuan dan kemudian diendors sebagai perintah mahkamah. Abdul Monir Yaacob (2006: 234-248) juga berpandangan penyelesaian terbaik bagi kes tuntutan harta sepencarian adalah melalui persetujuan atau șulh.

Ahmad Hidayat (2007: 338) dalam membincangkan berkaitan prinsip dan pelaksanaan hibah di Malaysia, turut menyentuh berkaitan pendekatan șulh di dalam kes pengesahan hibah di Mahkamah Syariah. Penulis menyentuh soal harta hibah yang masih dalam gadaian boleh diberi keizinan atau perlepasan dari pemiutang sama ada melalui proses șulh, ibrä', daman atau takaful. Melalui kaedah șulh penyelesaian mampu dicapai bagi kes-kes yang rumit seperti kes hibah harta yang dibicarakan di Mahkamah Syariah.

Penulisan yang lebih khusus bagi mengkaji kes-kes yang secara langsung melibatkan bidangkuasa Mahkamah Tinggi Syariah yang berbidangkuasa dalam membicarakan kes-kes yang dilaporkan di dalam Jurnal Hukum melibatkan wakaf, hibah dan wasiat didapati melalui tulisan Umar A.Oseni (2011). Penulisan ini telah membincangkan pendekatan Alternative Disputes Resolution (ADR) yang melibatkan șulh, majlis tahkim dan sebagainya bagi tujuan penyelesaian kes tuntutan harta wakaf, hibah dan wasiat di Mahkamah Syariah. Zati Ilham Abdul Manaf (2017) turut mengkaji kewajaran untuk mewujudkan sebuah tribunal khusus bagi menyelesaikan kes-kes pertikaian berkaitan tanah wakaf yang berlaku dewasa ini. Berpandukan kepada kes-kes yang dilaporkan bermula tahun 2005 hingga 2016 dan isu-isu yang berbangkit, penulis berpendapat kewujudan tribunal ini adalah satu mekanisme cadangan yang menggunapakai kaedah ADR bagi tujuan menyelesaikan pertindihan bidang kuasa yang wujud di antara Mahkamah Sivil dan Mahkamah Syariah kini.

Terdapat juga penulisan yang menyentuh sulh secara ringkas atau tidak langsung khususnya perbincangan berkaitan tentang harta sepencarian, wakaf, hibah, wasiat dan pusaka orang-orang Islam di Malaysia. Mohd Norhusairi 
(2016: 75-88) mengkaji berdasarkan kajian lepas tentang amalan pembahagian harta sepencarian di Malaysia. Penulis mendapati șulh adalah pendekatan yang banyak dipilih bagi penyelesaian kes-kes pertikaian harta sepencarian di Mahkamah Syariah. Mohd. Zamro (2008) pula mengkaji tentang instrumen hibah dan wasiat dari aspek analisis hukum dan aplikasinya di Malaysia. Manakala Jasni Sulong (2005) membincangkan berkaitan undang-undang pusaka Islam dan cadangan ke arah pembaharuan undang-undang berkenaan di Malaysia. Dalam penyelesaian kes pusaka orang-orang Islam, penulis berpendapat dengan kaedah sulh, keutamaan pemilikan hartanah terbabit dapat diperolehi oleh ahli waris yang layak atau mendapatkan nilai yang perlu dibayar kepada waris yang lain (Jasni Sulong, 2011: 124). Hasil penemuan penulisan tersebut mendapati pendekatan șulh atau muafakat sama ada secara rasmi atau tidak rasmi dianggap sebagai pendekatan alternatif bagi penyelesaian kes melibatkan hartanah orang-orang Islam melalui persepakatan ahli waris dan mengelak melalui proses perbicaraan yang memakan kos dan masa yang panjang.

Penulisan-penulisan yang dihasilkan tersebut banyak merujuk kes-kes pertikaian melibatkan harta alih dan harta tidak alih atau campuran keduaduanya yang telah diputuskan oleh Mahkamah Syariah. Kajian-kajian kes tersebut tertumpu kepada aspek hujahan pihak-pihak dan alasan penghakiman serta keputusan atau perintah yang telah dikeluarkan oleh mahkamah. Kajian dari aspek proses pelaksanaan majlis sulh yang dijalankan tidak diberi tumpuan oleh para pengkaji. Seharusnya kajian terhadap keberkesanan șulh bagi mencapai penyelesaian alternatif antara pihak-pihak bertikai masih perlu dikembangkan secara komprehensif.

\section{KESIMPULAN}

Penulisan-penulisan terdahulu telah menjelaskan kedudukan șulh sebagai alternatif penyelesaian secara damai dan berkesan bagi mengelak pihakpihak yang bertikai meneruskan perbicaraan di mahkamah terbuka yang memakan masa dan kos yang lebih banyak. Pelaksanaan șulh atau konsepnya lebih mirip kepada mediasi di mahkamah sivil adalah sebahagian daripada kaedah penyelesaian alternatif yang digunapakai dalam sistem kehakiman sivil di seluruh dunia. Berdasarkan pemerhatian pengkaji, penulisan-penulisan berkaitan mediasi dan penyelesaian pertikaian alternatif atau Alternative Dispute Resolusian (ADR) menjadi suatu topik kajian yang semakin berkembang kini. Di Malaysia, șulh telah diamalkan di Mahkamah Syariah dan mempunyai punca kuasa perundangan yang tersendiri. Terdapat beberapa kajian terdahulu yang melihat aspek pelaksanaan șulh di Mahkamah Syariah, 
namun kajian tersebut agak terhad pada sudut penyelesaiaan kes kekeluargaan sahaja dan difokuskan kepada Mahkamah-mahkamah Syariah tertentu khususnya di Mahkamah Syariah Wilayah-wilayah Persekutuan dan Selangor. Pembahagian dua kategori Mahkamah Syariah di Malaysia iaitu kategori Mahkamah Syariah negeri guna sama dan Mahkamah Syariah negeri tidak guna sama yang mempunyai pentadbiran dan pengurusan pelaksanaan șulh yang berbeza seharusnya dibuat kajian yang lebih lanjut.

Berdasarkan kepada sorotan literatur yang dibincangkan, pengkaji mendapati bahawa penulisan berkaitan pelaksanaan șulh di Mahkamah Syariah masih belum meluas. Isu-isu perundangan dan pentadbiran adalah aspek yang seharusnya dikaji lebih lanjut terutama bagi melihat șulh sebagai satu kaedah alternatif bagi menyelesaikan pertindihan bidangkuasa di antara Mahkamah Syariah dan Mahkamah Tinggi Sivil atau institusi-institusi yang terlibat dalam kes-kes melibatkan hartanah orang-orang Islam. Dari aspek perundangan semasa memperlihatkan Arahan-arahan Amalan Mahkamah dan Pekeling-pekeliling pentadbiran JKPTG terkini sentiasa dikeluarkan dan dikemas kini bagi melicinkan pelaksanaan șulh dan pentadbiran tanah. Namun masih terdapat kesamaran dalam penafsiran sesetengah peruntukan seperti peruntukan seksyen 421A Kanun Tanah Negara 1965 yang disebut perintah pembahagian Mahkamah Syariah hanya terhad kepada perintah pembahagian kes harta sepencarian sahaja. Kekeliruan seperti ini menyebabkan penguatkuasaan perintah Mahkamah Syariah terbantut di sesetengah Pejabat Tanah Jajahan. Isu-isu ini menjadikan pelaksanaan șulh berhadapan dengan cabaran dan prospek masa depan yang lebih cerah bagi penyelesaian segera kes-kes tuntutan melibatkan hartanah orang-orang Islam di Malaysia.

Oleh sebab pelaksanaan șulh atau mediasi adalah suatu pendekatan yang masih pesat berkembang dan menjadi pilihan orang ramai di Mahkamah Syariah, maka penulisan-penulisan mengenai pelaksanaan șulh dalam penyelesaian kes tuntutan melibatkan hartanah orang-orang Islam di Malaysia perlu diperluaskan. Kajian pelaksanaan șulh di Mahkamah Tinggi Syariah yang berbidangkuasa untuk membicarakan kes-kes tuntutan harta sepencarian, hibah, wakaf, pengesahan pusaka dan wasiat orang-orang Islam di Malaysia merupakan suatu keperluan bagi menilai sejauhmana keberkesanan șulh mampu menyelesaikan kes-kes tuntutan tersebut dengan berkesan. Saranansaranan ke arah penambahbaikan pelaksanaan șulh amat perlu dikemukakan bagi memperkasakan Mahkamah Syariah untuk menjamin keadilan dan kepentingan pihak-pihak. Kajian ini seterusnya menyumbang ke arah perkembangan bidang pengajian berkaitan sulh dan penyelesaian terhadap konflik bidangkuasa institusi-institusi pentadbiran hartanah orang-orang Islam di Malaysia. 
Secara kesimpulannya, penulisan dan kajian yang dijalankan terdahulu mendapati șulh telah berperanan sebagai satu mekanisme bagi penyelesaian kes secara ringkas dan menjimatkan masa serta kos pihak-pihak dan mahkamah khususnya berkaitan kes-kes kekeluargaan. Pelbagai kajian yang menggunakan kaedah penyelidikan sama ada secara kualitatif atau kuantitatif menghasilkan dapatan kajian yang melihat pelaksanaan șulh mampu untuk terus dipertingkatkan bagi menghadapi cabaran masa depan. Namun kajian terhadap isu-isu pelaksanaan șulh di Mahkamah Syariah khususnya berkaitan kes-kes tuntutan hartanah orang-orang Islam dan peningkatan profesionalisme Pegawai Șulh di Mahkamah Syariah masih dilihat sebagai satu keperluan.

\section{RUJUKAN}

Abdul Aziz Ismail (2014). "Bidangkuasa Mahkamah Syariah dalam Pentadbiran Tanah", Jurnal Pentadbiran Tanah JKPTG, vol. 4, no. 1, 25-48.

Abdul Hamid Mohamad (2016). "Harmonization of Shariah and Civil Law in Malaysia: Is it Possible?" dalam Konflik dan Pengharmonian: Konflik Bidang Kuasa dan Pengharmonian Undang-Undang, ed. Shamrahayu Abdul Aziz. Kuala Lumpur: IKIM.

Abdul Monir Yaacob (2016). Mahkamah Syariah Perkembangan Pentadbiran Undang-Undang Islam di Malaysia. Cyberjaya: Selangor: Universiti Islam Malaysia.

Abdul Monir Yaakob (2006). "Harta Sepencarian," dalam Manual UndangUndang Keluarga Islam, ed. Abdul Monir Yaacob \& Siti Shamsiah Md Supi. Kuala Lumpur: IKIM, 415-438.

Abū Muḥammad 'Abd Allāh Ibn Aḥmad Ibn Muḥammad Ibn Qudāmah alMaqdisī (1995). al-Mughnī, vol. 6. Makkah: Maktabah al-Tijāriyyah.

Adzidah Yaakob, Mohammad Zaharuddin Zakaria, Asmidah Ahmad, Kamilah Wati Mohd \& Mustafa 'Afifi Ab Halim (2016). Pengenalan dan Keberkesanan Sulh di Mahkamah Syariah. Nilai, Negeri Sembilan: Penerbit USIM.

Ahmad Hidayat Buang (2007). "Prinsip dan Pelaksanaan Hibah," dalam Undang-Undang Islam di Malaysia: Prinsip dan Amalan, ed. Ahmad Hidayat Buang. Kuala Lumpur: Penerbit Universiti Malaya, 329-350.

Ahmad Hidayat Buang (2007b). "Prosedur Mal di Mahkamah Syariah," dalam Undang-Undang Islam di Malaysia: Prinsip dan Amalan, ed. Ahmad Hidayat Buang. Kuala Lumpur: Penerbit Universiti Malaya, 145-172. 
Ahmad Ibrahim (1965). "Law of Property," dalam Islamic Law in Malaya, ed. Ahmad Ibrahim. Singapore: Malaysian Sociological Research Institute Ltd., 245-314.

Ahmad Ibrahim (1989). "Common Law di Malaysia," Kanun: Jurnal UndangUndang Malaysia, vol. 3, no. 1, 3-25.

Ahmad Ibrahim (1995). "Sistem Kehakiman Islam di Malaysia," Jurnal Hukum, vol. 10, no. 1, 1-10.

Ahmad Ibrahim (2000). "Civil Law and Shariah Law: Conflict of Jurisdiction," dalam The Administration of Islamic Law in Malaysia, ed. Ahmad Mohamed Ibrahim. Kuala Lumpur: Penerbit IKIM, 37-60.

Aida Othman (2001). "Alternative Dispute Resolution (ADR) in Malaysia: Prospects and Challenges," Malayan Law Journal, vol. 2, ccxxiv-ccxliv.

Aida Othman (2005). "And Sulh is Best: Amicable Settlement and Disputes Resolution in Islamic Law," Tesis Doktor Falsafah, Harvard University.

Ainul Jaria Maidin (2014). "Peninsular Malaysia Land Administration System: A Historical Analysis," Jurnal Pentadbiran Tanah JKPTG, vol. 4, no. 1, $1-24$.

Al-Nasafi (1997). Talabah al-Ṭalabah. Bayrūt, Lubnan: Dār al-Kutub al'Ilmiyyah.

Al-Nazzam (t.t.). Al-Fatawā al-Hindiyyah. Bayrūt, Lubnan: Dār al-Ma'rifah.

Al-Sharbīn̄̄, Shams al-Dīn Muhammad Ibn Muḥammad al-Khātị (1944). Mughnī al-Muhtāj ilā Ma 'rifātī Ma'ānī Alfāz al-Minhāj, vol. 2. Bayrūt: Dar Ihyyā' al-Turāth.

Aseel al-Ramahi (2008). "Sulh: A Crucial Part of Islamic Arbitration," LSE Law, Society and Economy Working.

Dahlan, Nur Khalidah, Mohd Rizal Palil, Mohamad Abdul Hamid, Yaakub \& Nur Inayah Yaakob (2017). "Kaedah Penyelesaian Pertikaian Alternatif dari Sudut Syarak di Malaysia,” Journal of Nusantara Studies, vol. 2, no. 1, 86-98.

E. N. Taylor (1948). "Aspects of Customary Inheritance in Negeri Sembilan," Journal of the Royal Society Malayan Branch, vol. 21, no. 2, 41-130.

Faridah Jalil \& Rohizan Halim (2014). "Penggunaan Sulh (Mediasi) dalam kes Penukaran Agama, dalam Penyelesaian Pertikaian: Mekanisme dan Perundangan, ed. Sakinah Shaik Ahmad Yusoff, Kamal Halili Hassan, Suzanna Mohamed Isa. Bangi Selangor: Penerbit Universiti Kebangsaan Malaysia, 112-123. 
Halimah Yaacob (2012). Alternatif Dispute Resolution (ADR) Expanding Options in Local and Cross Islamic Finance Cases. Kuala Lumpur: ISRA.

Hanis Wahed (2015). "Sulh: Its Application in Malaysia," IOSR Journal of Humanities and Social Science Ver. II, vol. 20, no. 6, 71-79.

Hussin N. \& Ramizah Wan Muhamad (2008). "Sulh in Islamic Criminal Law: Its Application in Muslim Countries". Paper presented at the 4th Asia Pacific Mediation Forum Conference -Mediation in the Asia Pacific: Constraints and Challenges, Kuala Lumpur.

Jasni Sulong (2005). "Undang-undang Pusaka Islam: Kajian Terhadap Pembaharuan Undang-undang dan Aplikasinya di Malaysia," Tesis Doktor Falsafah, Jabatan Syariah dan Undang-undang, Akademi Pengajian Islam Universiti Malaya.

Jasni Sulong (2011). Pembaharuan Undang-Undang Pentadbiran Pusaka Islam. Pulau Pinang: Penerbit Universiti Sains Malaysia.

Kamal Halili Hassan, Norsuhaida Che Musa (2014). "Penyelesaian Pertikaian: Satu Sorotan" dalam Penyelesaian Pertikaian: Mekanisme dan Perundangan, ed. Sakinah Shaik Ahmad Yusoff, Kamal Halili Hassan \& Suzanna Mohamed Isa. Bangi, Selangor: Penerbit Universiti Kebangsaan Malaysia, 13-39.

Kamal Halili Hassan, Rohaida Nordin(2014). "Peranan Penyelesaian Alternatif di dalam Pertikaian Perusahaan: Pendekatan Sivil dan Syariah," dalam Penyelesaian Pertikaian: Mekanisme dan Perundangan, ed. Sakinah Shaik Ahmad Yusoff, Kamal Halili Hassan, Suzanna Mohamed Isa. Bangi, Selangor: Penerbit Universiti Kebangsaan Malaysia, 124-135.

M.B. Hooker (1970). Readings in Malay Adat Laws. Singapore: Singapore University Press.

M.B. Hooker (1972). Adat Laws in Modern Malaya. Kuala Lumpur: Oxford University Press.

Mazni Abdul Wahab (2014). "Pemerkasaaan Mahkamah Syariah Melalui Pemakaian Arahan Amalan Jabatan Kehakiman Syariah Malaysia," Tesis Doktor Falsafah, Jabatan Syariah dan Undang-Undang, Akademi Pengajian Islam, Universiti Malaya, Kuala Lumpur.

Md. Akhir Hj Yaacob (1990).Undang-undang Sivil Islam. Kuala Lumpur: Dewan Bahasa dan Pustaka.

Md. Yazid Ahmad \& Ibnor Azli Ibrahim, "Bidang Kuasa Mahkamah Syariah dalam Kes Tuntutan Harta Orang Islam di Malaysia," Jurnal Islamiyyat: International Journal of Islamic Studies, vol. 30 (2008), 99-127. 
Mohammad Hafiz Mohd Zaki, Mazbah Termizi \& Muhammad Ridhwan Saleh (2017). "Mediation v Sulh: A Comparative", Kertas Prosiding, International Conference on Dispute Resolution, Modern Trends in Effective Disputes Resolution, Universiti Islam Antarabangsa Malaysia (UIAM) pada 9-10 Ogos 2017.

Mohd Fuad Mohd Salleh, Jamilah Othman (2008). "Peranan Pegawai Sulh dalam Penyelesaian Konflik Keluarga Islam," JUTEKS: Jurnal Teknikal \& Kajian Sosial, vol. 7, 37-48.

Mohd Nazri Abd. Rahman (2010). Undang-Undang Tatacara Mal di Mahkamah Syariah: Prinsip dan Amalan. Negeri Sembilan: Karya Kreatif Resources.

Mohd Norhusairi Mat Hussin(2016). “Amalan Pembahagian Harta Sepencarian di Malaysia: Satu Sorotan Literatur,” Journal of Shariah Law Research, vol. 1, no. 1, 75-88.

Mohd. Ridzuan Awang (2008). "Pengurusan Pusaka dan Wasiat Orang Islam di Malaysia," Kertas Prosiding di Konvensyen Kebangsaan Pengurusan Harta Pusaka, Wasiat dan Wakaf Taman Tamadun Islam, Kuala Terengganu, Terengganu pada 18 \& 19 Oktober 2008.

Mohd. Zamro Muda (2008). "Instrumen Hibah dan Wasiat: Analisis Hukum dan Aplikasi di Malaysia," Kertas Kerja, Konvensyen Faraid dan Hibah Kebangsaan 2008.

Muḥammad Amīn Ibn 'Ābidīn (1966). Radd al-Muḥtār 'ala al-Durr alMukhtār Sharh Tanwīr al-Abṣār, vol. 8. Damascus: Dār al-Fikr.

Nora Abdul Hak (2007). "Family Mediation in Asia: A Special Reference to the Law and Practice in Malaysia," IIUM Law Journal, 121-148.

Nora Abdul Hak, Sa'odah, Ahmad \& Umar A. Oseni (2011). Alternative Dispute Resolution (ADR). Batu Caves, Selangor: IIUM Press.

Norjihan Ab. Aziz \& Nasimah Hussin (2016). "The Application of Mediation (Șulh) in Islamic Criminal Law," Jurnal Syariah, vol. 24, no. 1, 115-136.

Raihanah Azahari (2004). "Pelaksanaan Șulh di Jabatan Kehakiman Syariah Selangor Darul Ehsan (JAKESS): Satu Sorotan Awal,” Jurnal Syariah, vol. 12 , no. $2,43-78$.

Raihanah Azahari (2005). "Sulh dalam Perundangan Islam: Kajian di Jabatan Kehakiman Syariah Selangor Darul Ehsan (JAKESS)". Tesis Doktor Falsafah, Jabatan Fiqh Usul, Akademi Pengajian Islam, Universiti Malaya, Kuala Lumpur.

Raihanah Azahari (2008). Sulh dalam Kes Kekeluargaan Islam. Kuala Lumpur: Penerbit Universiti Malaya. 
Raihanah Azahari (2009). "Methodologi Sulh dalam Aspek Kekeluargaan Islam," Jurnal Institut Latihan Islam Malaysia (ILIM), vol. 2, 99-128.

Raini Hassan, Khan H. A., Imad Fakhri Al Shakili, Nora Abdul Hak (2013). "Setting-up a Sulh-based, Community Mediation-type of Online Dispute Resolution (ODR) in Malaysia," 5th International Conference on Information and Communication Technology for the Muslim World.

Ramizah Wan Muhamad (2005). "Sulh sebagai Alternatif Penyelesaian Kes di Mahkamah Syariah," dalam Kaedah Perundangan Bidangkuasa dan Tatacara Mahkamah Syariah, ed. Farid Sufian Shuaib, Mohd. Hisham Mohd Kamal \& Tajol Aris Ahmad Bustami. Kuala Lumpur: Dewan Bahasa Pustaka, 128-141.

Ramizah Wan Muhamad (2008). "The Theory and Practice of Sulh (Mediation) dalam the Malaysian Syariah Courts," IIUM Law Journal, vol. 16, 3335 .

Rusnadewi Abdul Rashid (2013). "Memartabatkan Undang-Undang Islam dan Mahkamah Syariah dalam Undang-Undang Tanah di Malaysia," Jurnal Hadhari, vol. 5, no. 2, 27-36.

Said Bouheraoua (2010). "Foundation of Mediation in Islamic Law and Its Contemporary Application," dalam Mediation in Malaysia: The Law and Practice, ed. Mohammad Naqib Ishan Jan, Ashgar Ali \& Ali Mohamed. Petaling Jaya: LexisNexis, 385-396.

Salleh Buang (1993). Undang-Undang Tanah di Malaysia. Kuala Lumpur: Dewan Bahasa dan Pustaka.

Saodah Ahmad, Rojanah Kahar \& Muslihah Hasbullah (2013). "Mediasi sebagai Kaedah Penyelesaian Pertikaian Alternatif dalam Pertikaian Keluarga," Jurnal Institut Latihan Islam Malaysia (ILIM), vol. 6 (2013),107-129.

Sayyid Sābiq (1990). Fiqh al-Sunnah, vol. 3. Qāhirah: Dār al-Diyān li alTurāth.

Shafi Fazaluddin (2016). "Conciliation Ethics in the Qur'an," Int J Semiot Law, vol. 29, 333-358.

Sheikh Ghazali Abdul Rahman (2005). "Amalan-Amalan Pentadbiran di Mahkamah Syariah,” Jurnal Hukum, Jld. XX/BHG.II, 164-187.

Sheikh Ghazali Abdul Rahman (2006b). "Penyelesaian Kes-kes Kekeluargaan Melalui Manual Kerja Sulh," dalam Manual Undang-Undang Keluarga Islam, ed. Abdul Monir Yaacob \& Siti Shamsiah Md Supi. Kuala Lumpur: IKIM, 243-260. 
Suwaid Tapah (2007). "Harta Perkahwinan (Harta Sepencarian)," dalam Undang-Undang Islam di Malaysia: Prinsip dan Amalan, ed. Ahmad Hidayat Buang. Kuala Lumpur: Penerbit Universiti Malaya, 55-78.

Syed Khalid Rashid (2004). "Alternative Dispute Resolution in the Contexts of Islamic Law". The Vindobons Journal of International Conventional Law and Arbitration, vol. 8, no. 1, 95-118.

Teo Keang Sood \& Khaw Lake Tee (2012). The Malaysian Torrens System: Historical Background Land Law in Malaysia: Cases and Commentary. Petaling Jaya, Selangor: Lexis Nexis.

Umar A. Oseni (2011). “The Legal Frame work of Alternative Disputes Resolution in Courts with Shariah Jurisdiction in Nigeria, Malaysia and Singapore," Tesis Doktor Falsafah, Ahmad Ibrahim Kuliyyah of Laws, Universiti Islam Antarabangsa Malaysia, Kuala Lumpur.

Wahbah al-Zuhaylī (1989), al-Fiqh al-Islāmī wa Adillatuh. Dimashq: Dār alFikr.

Wan Halim Othman (1996). "Community Mediation in Malaysia," dalam Constructive Conflict Management: Asia Pacific Cases, ed. Fred E. Jandt \& Paul B. Pedersen. London and New Delhi: Sage Publications.

Zaini Nasohah, Wafaa Yusuf \& Amir Husin Mohd. Nor (2010). "Perlaksanaan Sulh di Mahkamah Syariah," dalam Isu Perundangan Islam di Malaysia, ed. Anwar Fakhri Omar, Zaini Nasohah \& Abdul Basir Mohamad. Bangi, Selangor: Jabatan Syariah, Fakulti Pengajian Islam, Universiti Kebangsaan Malaysia, 72-84.

Zainul Rijal Abu Bakar (2011). "Sulh in Malaysian Syariah Courts," Kertas Kerja, 2nd AMA Conference: Rediscovering Mediation in the 21st Century, Sheraton Imperial Hotel, Kuala Lumpur.

Zati Ilham Abdul Manaf (2017). "Resolution of Waqf Land Disputes: The Relevance of A Waqf Tribunal in Malaysia," Kertas Prosiding, International Conference on Dispute Resolution, Modern Trends in Effective Disputes Resolution, Universiti Islam Antarabangsa Malaysia (UIAM) pada 9-10 Ogos 2017.

\section{Senarai Statut}

Akta Keterangan 1950

Akta Memperbaharui Perkahwinan dan Perceraian 1976

Akta Pembahagian Pusaka Kecil 1955

Akta Probet dan Pentadbiran 1959 
Akta Prosedur Mal Mahkamah Syariah Persekutuan 1998

Akta Relif Spesifik 1950

Akta Tanah (Kawasan Penempatan Berkelompok) 1960

Akta Tatacara Mal Mahkamah Syariah (Wilayah-wilayah Persekutuan) 1998

Enakmen Tatacara Mal Mahkamah Syariah (Negeri Sembilan) 2003

Kanun Tanah Negara 1965

Ordinan Undang-Undang Sivil 1937

Piagam Keadilan Tahun 1826

\section{Senarai Kes}

Ramah lwn Laton (1927) 6 FMSLR 128

Shaikh Abdul Latif \& Ors v Shaikh Elias Bux (1915) 1 FMSLR 204

Tengku Jaafar \& Anor lwn State of Pahang (1987) 2 MLJ 74 
Journal of Shariah Law Research (JSLR) 